Article

\title{
Sustainable Innovation in Small Medium Enterprises: The Impact of Knowledge Management on Organizational Innovation through a Mediation Analysis by Using SEM Approach
}

\author{
Jaffar Abbas $\left.{ }^{1}{ }^{(}\right)$, Qingyu Zhang ${ }^{2, *}$, Iftikhar Hussain ${ }^{3}$, Sabahat Akram ${ }^{4}\left(\mathbb{D}\right.$, Aneeqa Afaq ${ }^{5}$ and \\ Muhammad Afzal Shad ${ }^{6}(\mathbb{D}$ \\ 1 Antai College of Economics and Management (ACEM), School of Media and Communication (SMC) of \\ Shanghai Jiao Tong University (SJTU), No. 800 Dongchuan Road Minhang District, Shanghai 200240, China; \\ abbas512@sjtu.edu.cn \\ 2 Research Institute of Business Analytics \& Supply Chain Management, College of Management, \\ Shenzhen University, Shenzhen 518060, China \\ 3 Dean Faculty of Computing \& Engineering, University of Kotli Azad Jammu \& Kashmir, \\ Azad Kashmir 11100, Pakistan; iftikhar_raja@live.com \\ 4 Department of Economics, University of Kotli Azad Jammu \& Kashmir, Azad Kashmir 11100, Pakistan; \\ sabahat_abrar@hotmail.com \\ 5 Department of Public Administration, University of Kotli Azad Jammu \& Kashmir, Azad Kashmir 11100, \\ Pakistan; aneeqa_001@yahoo.com \\ 6 Department of Commerce, University of Kotli Azad Jammu \& Kashmir, Azad Kashmir 11100, Pakistan; \\ afzaalshaad@gmail.com \\ * Correspondence: q.yu.zhang@gmail.com
}

Received: 8 February 2020; Accepted: 2 March 2020; Published: 19 March 2020

\begin{abstract}
This current study is among the very few investigations, which seeks the relationship between knowledge management and sustainable organizational innovation in garment business firms. This investigation focused on examining how organizational learning mediates the relationship between knowledge management and sustainable organizational innovation. This research establishes that knowledge management and organizational innovation procedures are integral parts of the progress and survival of the organizations. The received data of this population reports on the garment firms, operating their businesses in Lahore and Gujranwala. The study applied a stratified random sampling method for data collection and employed structural equation modeling (SEM) to examine the hypothesized relationships. The results specify that knowledge management shows a significant positive association with organizational learning, which in turn reveals a positive linkage to sustainable organizational innovation in SMEs of the garment industry. The study results also specify that organizational learning mediates the relationship between knowledge management and sustainable organizational innovation. This research survey identifies the significance of knowledge management and organizational learning in executing the process of organizational innovation, and it helps business managers to understand organizational learning as a mediator, which in turn indicates the benefits of knowledge management in achieving sustainable organizational innovation. This review provides an empirical indication of original data to investigate the linkage between knowledge management, sustainable innovation process, and organizational learning culture in the Pakistani garment sector. The generalizability of the study fallouts is restricted to the garment industry, and it offers valuable insights for imminent researchers.
\end{abstract}

Keywords: innovation; SMEs; organizational learning; knowledge management; Pakistan 


\section{Introduction}

Since the intensification of knowledge management, the values in the process of organizational innovation is taking place increasingly in the business industry [1]. Business firms intensely observe an indispensable role of organizational innovation, feasibility endurance, and success by the capacity of grasping the enshrouded value of critically attained, implicit, and explicit knowledge [2]. In recent years, services or products of traditional labor and innovative organizations have progressively substituted with unceasing revolution by customers' needs, necessities, and demands through knowledge-based businesses [3,4]. Knowledge management is categorically a dynamic factor for business organizations, predominantly garments, and textile industry [5]. In today's competitive and turbulent market, knowledge management sharing plays an indispensable role in creating new knowledge in the process of sustainable innovation in organizations. In an earlier study, Barachini (2009) recognizes that business firms have to inspire their workforce to share critical information and knowledge regularly to grasp and reuse in hand knowledge assets [6]. Typically, scholars focus on the organization's idea of developing knowledge management and supportive culture for the innovation process.

Business firms seek to build a knowledge-friendly strategy, which helps them in sharing, transmitting, and reusing valuable insights. Instantaneously, business companies take measures in introducing methods of useful knowledge sharing and procedures of innovation in daily business operations to enhance creativity, innovation, and business performance worldwide s. In the present unstable economic environment, globalization, innovation, rapid technological advancements have become strategic and financial drivers. The process of innovation in a business organization heavily relies on the availability of knowledge. Access to knowledge enhances innovation, which helps business organizations to achieve valuable benefits, effectiveness, sustainability, growth, and economic prosperity [7]. Sustainable organizational innovation (SOI) is a continuous process of perceiving, exploring, and learning, which enables enterprises and business organizations to innovate new procedures in business organizations, new markets, new and improved products, and services [8]. Presently, knowledge management (KM) is a well-established and recognized field of study. Lin [9] defined KM as flow and sharing of knowledge inside an industry or a firm. The studies have explored that KM empowers firms to create modern methods to realize viable benefits, effectively attaining knowledge, and improve sustainable organizational innovation [10]. In views of Park, Ribière [11], "Today's world economy is recognized as enormous competitiveness in businesses, establishing learning systems, creating products and services mergers and adopting and managing rapidly changing technologies. Such kind of competitive and energetic business environment ask for managing organizational knowledge even more competitively."

Wiig [12] clarified knowledge management by defining it as a range of clearly described procedures, methods, and techniques employed to find out valuable information in different administrative procedures. He determined knowledge management's purpose was primarily to empower business in alternative perspectives, first to secure its prospects and achievements, after that, concentrate on building a firm or industry to sensibly, considering its knowledge assets. Though, the overall aim of KM is to improve organizational competitiveness [13]. Knowledge management is the source of organizational achievement and a significant source in empowering businesses to produce innovative goods and services as well as grow new-markets and bringing sustainability in companies. Moreover, Adams and Lamont [7] recorded in their research work that knowledge management is a vital source for realizing continuous innovation resulting in competitive and sustainable benefits. Effective knowledge management can bring immediate paybacks and improvement in workforce productivity, increase services value, and competitive advantages through creativity and consequently brings sustainability in firms [10].

According to Levinthal and March [14], organizational learning (OL) ensued as an added ability to compete with the changes takes place due to the influential and unstable organizational environment. Organizational learning leads to better output and acts as a tool to control and improve the performance 
of a business as well as realize ongoing organizational accomplishments [15]. While the industry will progress to organizational innovation and the culture of OL motivates workers for creativity.

The garments and textile industry contribute almost $50 \%$ of Pakistan's exports and are the primary principal constituent of trade. Garments sector, because of current promising changes for the businesses in Pakistan and the probable future developments in the global world business edifice for the industry, can perform a significant part in increasing Pakistani exports. Besides, garments-manufacturing echoes with Pakistan's policy to help in saving and generating resources for employment and economic growth due to the sector's capital intensive and energy saving nature $[16,17]$. Considering the economics as well as the employment importance of this sector, the researchers selected this sector.

The primary concern of the current study was theory related, i.e., examining the relationships between acknowledgment management, sustainable organizational innovation, and organizational learning. Existing knowledge management literature designates that already employed methods were uncertain, and the statistical link among knowledge management and organizational learning has not been principally stated [18]. The current research concentrated on the new and original methods of calculating the association between knowledge management, sustainable organizational innovation, and organizational learning. Further, in what way the statistical connection can form virtuous debate concerning innovation procedures. The current research focuses on addressing the literature gaps highlighted above, and it attempted to examine the association between knowledge management and sustainable organizational innovation. At the same time, organizational learning was taken as a mediating variable by addressing the literature gap means the missing statistical link between the studied variables and the literature gap in terms of the garments industry, SMEs, and developing countries like Pakistan.

\section{Critical Literature Analysis}

\subsection{The Linkage between Knowledge Management and Sustainable Organizational Innovation}

Each type of knowledge that is attained, created and disseminated is required to be supported by authorization and storing knowledge; otherwise, a business is perpetually in danger of fortuitously disremembering to acquire knowledge [19]. Andreeva and Kianto [20] emphasized that an enterprise puts a lot of effort into keeping it innovative, ensuring creativity and attaining sustainable competitive benefits if it does not store its critical knowledge in a proper place. Such kind of a system or site is also required to realize improved results of knowledge management for various kinds of sustainable innovations. Literature related to knowledge mentions that knowledge policies and strategies affect a business's performance via their abilities to innovate and sustain [21]. Authors, in their analytical research of New Zealand companies, concluded that companies employing knowledge management strategies were relatively innovative and had a better sustainable financial performance. This study finds regarding attaining knowledge about the market, for example, was essential for encouraging novelties that best suit customer needs. López-Nicolás and Meroño-Cerdán [22] in their study conducted in Spanish firms, concluded that knowledge management strategy impacts a sustainable firm performance by enhancing its innovative abilities and skills.

Given the above literature on knowledge management and sustainable organizational innovation, the following hypothesis was proposed to study and test the relationship between knowledge management and sustainable organizational innovation (KM and SOI):

Hypothesis 1. A direct relationship exists between the effectiveness of knowledge management processes used and the organization's ability for sustainable innovation. 


\subsection{The Relationship of Knowledge Management and Organizational Learning}

The link between knowledge management and organizational learning can be conceived through several activities. The focus of knowledge management is the content of the knowledge which a business creates, captures, and, finally, uses. Whereas the focus of organizational learning is the practice and implantation of knowledge [23]. Knowledge management covers the creation, acquisition, storing, and accumulating usage of knowledge. According to [24], a knowledge management system suggests a corporate setting that encourages organizational learning.

Knowledge management, especially knowledge sharing in a firm, ensues once a worker is ready to learn from and assist other workers in developing innovative abilities and skills [25]. In views of [26], learn means to digest, to absorb, or to apply. In a study conducted in the hoteling sector at Manhattan on sharing practices, the researchers found that the sharing of experience within a hotel as well as between other hotels in the industry has substantial positive consequences on day-to-day processes [27]. The same sort of findings was stated by Sveiby [28], he concluded that the flow of knowledge among workers help them to improve their skills and abilities and to create new and improved knowledge jointly.

The value of knowledge can be increased through sharing and transferring it to the rest of the individual working in the same organization or other. The depreciation of knowledge was defined by Argote [29] as the value lost by knowledge. The knowledge depreciation occurs in five different ways, and it is as follows. When an employee leaves a job and organization is unable to retain his knowledge. When current organizational knowledge becomes outdated, the firm momentarily becomes incompetent. When due to outdated knowledge, the innovative and new goods and services introduced by a firm becomes expensive or substandard products. Transfer knowledge is incomplete or knowledge shared is selective, or the knowledge sharing practices are adopted for some individuals only. When accessing organizational knowledge becomes hard. Argote [29] knowledge depreciation has adverse effects on sustainable organizational performance as well as OL by decreasing productivity level, declining customer satisfaction level, unable to meet delivery promises, incorrect strategic behavior, and resulting unsuitable decisions made by managers. Consequently, firms will become unsustainable, incompetent and ineffective.

The process of learning and sharing facilitates information interpretation or conversion to knowledge through improving individual absorptive ability, beliefs, and values. The method of sharing and learning regulates whether the information, as well as knowledge, is beneficial and useable after the course of interpreting [30,31]. The newly created knowledge and the use of existing knowledge will become different as a result of sharing and learning knowledge.

The business organizations need to employ the knowledge management process professionally to improve their learning competencies Liao and $\mathrm{Wu}$ [18]. Because of [32], those organizations that is not having a knowledge management system are unable to develop individual and organizational learning skills and abilities. Knowledge management flow and assembling throughout the business operations, specifically knowledge development, acts as a strategic source to learning [33]. The above-mentioned studies concluded that knowledge management empowers businesses to acquire the benefits of organizational efficiency and organizational learning. Therefore, we can draw a hypothesis as under:

Hypothesis 2. A direct relationship exists between the effectiveness of knowledge management processes used and the organization's ability to learn.

\subsection{The Linkage between Organizational Learning and Sustainable Organizational Innovation (OL \& SOI)}

Organizational learning is vital to the success of business firms [34]. Accordingly, in the current rapidly changing and challenging environment for companies tackled with poor learning abilities and producing on a large scale, it has become hard to take full advantage of their skills and abilities. 
In an ever-changing environment like today, only those businesses will be able to survive and grow, which will enable themselves to take full advantage of the abilities, skills, and learning capacities of all employees working in different sections of a business [35]. Organizational learning supports in attaining and submitting knowledge to improve creativity and ensure competitiveness through the development and provision of new and advanced products and services for sustainable growth [36]. Another study specified that many studies conducted on organizational learning had advanced the literature on sustainable organizational innovation [37]. A statistically significant and positive impact of learning on sustainable innovation was reported in many studies [18,38-42].

The firms having an active learning process are successful in providing their customers with innovative products and services as improved learning made them capable enough not to lose any opportunity to introduce products and services to meet ever-changing market demands. Such firms have appropriate knowledge and information to forecast and study customer requirements. These firms were also competent in terms of new and innovative technologies to innovate better and sustain. The organization having better learning processes are capable of judging its competitors' weaknesses and strengths, this helps such firms become more efficient and change their failures into success as well as introduce sustainable novel ideas and skills [43]. Another study reported a positive association among technical innovation and organizational learning [44] reported a positive association between technological innovation and organizational learning.

The organizational innovation capability is primarily influenced by three organizational elements, i.e., cultural innovativeness, learning, and market orientation [45]. The above-cited literature has investigated all directions of the relationship between organizational learning and sustainable organizational innovation. However, a positive link was reported in the majority of these studies, and these studies concluded that organizational learning enhances firms' ability to innovate [44,46]. Therefore, we can draw a hypothesis as follows.

Hypothesis 3. A direct relationship exists between the effectiveness of the organizational learning mechanism used and the organization's ability to innovate.

\subsection{The Relationship among Knowledge Management, Organizational Learning, and Sustainable Organizational Innovation}

Knowledge management is defined as a process through which a business identify, choose, produce, share and transmit valuable knowledge which is being implemented in organizational methods of problem identification and solution, dynamic training, thought-out planning and decision making [47-49]. Another study described that organizational learning encourages individuals to support each other in initiating organizational knowledge processes Wijnhoven [50]. Effective organizational learning processes offer better opportunities for people to collaborate, and such collaborations help in accessing, sharing, and using knowledge through better KM abilities. The implementation and success of organizational learning in a business organization ensures updating existing knowledge and its availability as well as contributing through innovative knowledge in achieving sustainability goals Gnyawali and Stewart [51,52]. Moreover, in a dynamic environment, organizational learning can store and share knowledge to maximize value creation and addition Drucker [53]. The ability to learn improves the firm's ability to create and use knowledge, Cohen and Levinthal [39].

The capable learning system provides updated information and well-organized advantages to business organizations worldwide. The organizational learning involves different learning processes and procedures where every organization and individual can progress. Such operations include requirements of the customers as well as keeping the organization updated and capable of meeting with the ever-changing market needs and wants to remain sustainable [43]. Innovation is defined as the process of creating, evaluating, and executing novel procedures and ideas. It is a worldwide-recognized 
component that organizational learning and sustainable organizational innovation are strongly interlinked to each other. Further, the scholars recommend that organizations should enhance their employees understanding of this correlation.

Organizations' ability to learn is known to be a planned tool for ensuring the constant achievement of a firm $[18,54,55]$. Some studies have reported organizational learning positively affects innovation position and dispersal $[56,57]$. Additionally, a healthy organizational learning system encourages creativity in business to remain sustainable $[58,59]$. Some studies reported that employees of an organization through their learning abilities share knowledge across the organization, which helps an organization in bringing sustainability through innovative as well as new products and services $[60,61]$.

The idea that innovation is essential to an organization to remain competitive, sustained, and successful was widely recognized [62-65]. Organizational innovation involves the formulation of innovative products and services, methods, and new ideas. It becomes evident that organizations' ability to learn and their ability to innovate is connected [45]. If we see as a system or process, knowledge management acts as an input. In contrast, organizational learning serves as a critical procedure, and organizational innovation is recognized as the primary output Liao and $\mathrm{Wu}$ [18]. We can conclude the above-cited literature to realize the benefits of innovation. Knowledge management system containing the ability to learn is vital. Little research has been conducted in Pakistan concerning studied variables. All these researchers studied one or two of these variables. None of these studies have considered all these variables in a single model, and secondly, these studies were conducted mostly in public sector organizations. Specifically, no investigation was undertaken in garments sector firms [19,66-68]. The relationship reported in the literature was checked through the following hypothesis:

Hypothesis 4. Organizational learning mediates the relationship between the effectiveness of knowledge management processes used and the organization's ability to innovate sustainably.

\subsection{The Hypothesized Model}

Keeping in view the literature cited and hypotheses developed in the light of current literature analysis, a research framework was proposed shown in Figure 1.

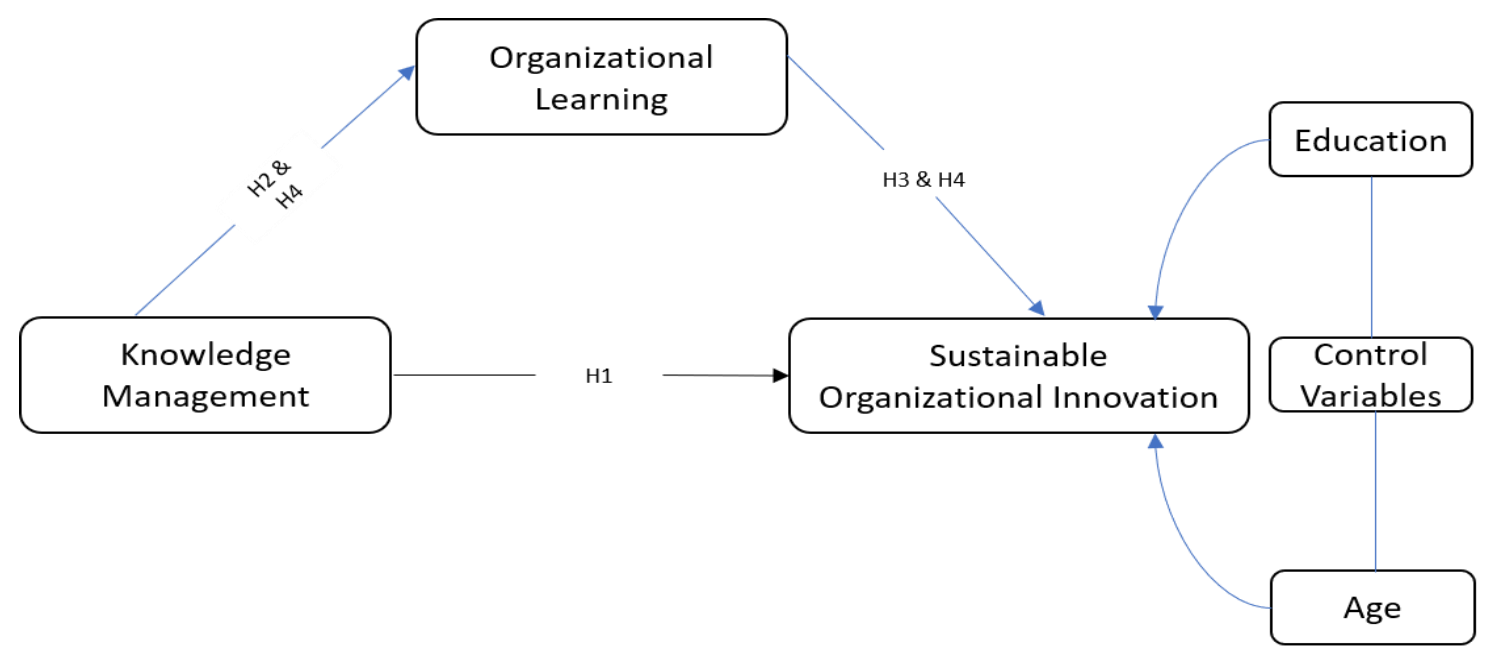

Figure 1. The hypothesized model.

\section{Materials and Methods}

The materials and methods were designed to explain specific methodologies employed for testing and describing the empirical relationship between the studied variables knowledge management, organizational learning, and organizational innovation. This section includes study design, research 
philosophy, target population, study sample, research instrument used for data gathering, data gathering methods, study framework or model, techniques used for analyzing data, and research ethics.

The choice and implementation of a specific research-philosophy help the researchers to clarify the overall research method to be used, evaluate available methods, and be innovative and progressive in selecting and altering techniques that were implemented previously [69]. Moreover, the concept of research philosophy is based on ideas, values, norms, organizational activities, and traditions. Research philosophy facilitates researchers in obtaining information and knowledge related to their area of study, and it is of three different forms, i.e., realism, positivism, and interpretivism McNabb [70].

A positivist approach was used in this study, as suggested by Creswell and Creswell [71]. The positivism approach is built on the judgments, scientific methods being followed, and causes, and their possible effects are being fixed [71,72]. Additionally, Mertens positivist approach is appropriate for a social or communal world with the prospect that the societal-world can be taken as the commonplace, employing an unbiased process that results in ordinary findings. However, according to Creswell, positivism philosophy concentrates on defining and describing the relationships, their causes, and impacts; it also simplifies the links and details for forecasting such relationships.

Saunders [73], based on nature, has categorized research studies into three forms explanatory, exploratory, and descriptive. Exploratory research tries to define a research problem initially and collects basic information concerning to identify a problem and helps establish further research. Explanatory research seeks to shape essential links among studied variables, while the descriptive study is conducted to express a precise figure of situations, individuals, or events. As suggested in Saunders [73], explanatory research, as well as cross-sectional examination, was employed in this research. This study intends to find the impact of knowledge management on organizational innovation and to check whether organizational learning can mediate the relationship between KM and organizational innovation. A cross-sectional design was employed in this study. The cross-sectional research tries to find the association among studied variables at a particular time. It describes the rise of a phenomenon that examined how the studied-variables are connected. The benefit of selecting a cross-sectional design is that it is comparatively economical and timesaving than a longitudinal study. In this study researcher employed structural equation modeling (SEM). The method of SEM is a set of statistical techniques that permits us to study relationships among independent and dependent variables, either one or more, as well as discrete or continuous. Variables or factors can measure the independent and dependent variables. SEM has alternative names such as simultaneous equation modeling, path analysis, causal analysis, causal modeling, confirmatory factor analysis, and analysis of covariance.

\subsection{Population and Sample}

The population under consideration for the present study included firms working in the garments industry of Gujranwala and Lahore divisions of Pakistan. Data were collected through a self-administered survey. A sampling frame was devised to contain all the garments sector firms situated in the targeted area and to support the selection of samples. A sample of 350 firms was selected for this research. The data from selected firms were gathered through a stratified random sampling technique, as stratified random sampling assists scientists to ensure that the chosen sample is a good representative of the population [74].

\subsection{Data Collection Instrument}

The close-ended, well-structured items were used to collect responses, close-ended items are an effective way of gathering adequate organized replies, which empower numerical analysis, examining hypotheses, and illustrating conclusions. The reactions concerning all study variables were measured through a Five-point Likert scale. 


\subsection{Data Collection Methods}

Groves and Couper [75] specified that for the creation of valuable data or information, the data-gathering is a significant component. For the present study, researchers initially contacted the targeted firms on the phone as well as through e-mails to get proper consent from them to collect data. Once the formal approval was received, the study survey was distributed to the respondent firms. The participants were informed and briefed about the questionnaire contents to understand it before fulfilling it ultimately. The survey participants were requested to respond to the survey in two weeks. After two weeks, the researchers themselves collected all the distributed questionnaires from participants. Similarly, follow-ups were completed by emails and telephones to improve survey participation. Subsequently, on receiving the duly filled responses, the respondents were acknowledged.

\subsection{Variables Measurement}

The reliability and validity of the questionnaire employed in the current study were measured and evaluated. This precise study evaluated knowledge management through five different constructs adopted from the previous studies, as described in Table 1. The selected constructs of knowledge management include expectations of associations with colleagues and peers, hopes of reward for sharing relevant information and knowledge employees contain, knowledge management attitudes, $\mathrm{KM}$ behavior, and expected contribution in the form of information and knowledge as indicated in Table 1.

Table 1. Knowledge management (KM) constructs.

\begin{tabular}{ccc}
\hline & Constructs \& Measures & Reference \\
\hline $\begin{array}{c}\text { Expectations of } \\
\text { Associations }\end{array}$ & $\begin{array}{c}\text { Individuals, after taking part in KM processes, expect better } \\
\text { ties and relations with their colleagues and peers. }\end{array}$ & [76-81] \\
\hline $\begin{array}{c}\text { Expectations of } \\
\text { Rewards }\end{array}$ & $\begin{array}{c}\text { Individuals in return of efforts put by them for the success of } \\
\text { KM expects to be rewarded by the organization. }\end{array}$ & [82-85] \\
\hline $\begin{array}{c}\text { Expected } \\
\text { Contribution }\end{array}$ & $\begin{array}{c}\text { Individuals believe that after their efforts for the success of } \\
\text { KM, the performance of the organization will improve. }\end{array}$ & [86-89] \\
\hline Attitude toward KM & $\begin{array}{r}\text { The pleasing feelings and sentiments individuals' show } \\
\text { while managing knowledge in organizations }\end{array}$ & [90-93] \\
\hline KM Behavior & Level of participation in KM by someone. & [94-97]
\end{tabular}

The available literature categorized organizations as early adopters, late adopters, innovators, and laggards in the literature that are cornering their level of innovation. The literature also classified innovation based on productivity as process innovation and product innovation, and the measures are taken considering inputs are resources spend on research and development, all these different measures were used and explained in the literature. As suggested and employed by Manu (1992), this study used three different types of innovation as measures for SOI, i.e., product innovation, process innovation, and administrative innovation, as illustrated in Table 2. 
Table 2. Sustainable organizational innovation (SOI) constructs.

\begin{tabular}{|c|c|c|}
\hline & Constructs \& Measures & Reference \\
\hline Product Innovation & $\begin{array}{l}\text { The efforts a firm put in the process of developing new } \\
\text { products or services in terms of persons, hours, teams, and } \\
\text { training involved. } \\
\text { Basic characteristics for introducing novel products or } \\
\text { services } \\
\text { Innovative products or services introduced by the firm. }\end{array}$ & [98-102] \\
\hline Process Innovation & $\begin{array}{l}\text { Changes introduced in the processes being used by a firm. } \\
\text { Efforts put into developing or introducing novel processes. } \\
\text { Smart reply to innovative processes employed by competing } \\
\text { firms }\end{array}$ & $\begin{array}{c}{[98-100,102,} \\
103]\end{array}$ \\
\hline $\begin{array}{l}\text { Administrative } \\
\text { Innovation }\end{array}$ & $\begin{array}{c}\text { The changes and innovations in the system being adopted by } \\
\text { a firm. } \\
\text { Efforts firms put in exploring new administrative systems. } \\
\text { Organizational thrusts to bring an innovative administrative } \\
\text { system }\end{array}$ & {$[98,99,101,102]$} \\
\hline
\end{tabular}

Organizational learning in this study was measured by focusing on Huber's model of OL. The researchers studied and analyzed measures used in the literature for OL [104-109]. Organizational variable learning was measured using four different dimensions of learning cited in the literature, i.e., acquiring, distributing, and interpreting knowledge as well as organizational memory. The study measured Organizational learning as a sole variable through a model having four dimensions, as discussed in Table 3.

Table 3. Organizational Learning (OL) constructs.

\begin{tabular}{|c|c|c|}
\hline & Constructs \& Measures & Reference \\
\hline $\begin{array}{l}\text { Acquiring } \\
\text { Knowledge }\end{array}$ & $\begin{array}{l}\text { Firms' workforce participation in different events and shows. } \\
\text { The research and development policy implemented in a firm is } \\
\text { unique and consolidated. } \\
\text { Firms consider and evaluate creative thoughts and tactics in the } \\
\text { workplace regularly. }\end{array}$ & {$[106,108,110]$} \\
\hline $\begin{array}{l}\text { Distributing } \\
\text { Knowledge }\end{array}$ & $\begin{array}{c}\text { A sound mechanism was adopted in a firm to confirm the } \\
\text { availability of the best practices across the organization. } \\
\text { Few individuals act as a link in a business organization as they } \\
\text { contribute in diverse teams and divisions. } \\
\text { Few individuals perform the job of collecting, storing, and } \\
\text { sharing ideas and suggestions created by organizational } \\
\text { employees. }\end{array}$ & {$[105,106,108,110]$} \\
\hline $\begin{array}{l}\text { Interpreting } \\
\text { Knowledge }\end{array}$ & $\begin{array}{l}\text { The overall employees of the organization put their dedicated } \\
\text { efforts to achieve commonly devised goals. } \\
\text { Employees share their expertise, knowledge, and experiences } \\
\text { during meetings and conversions. } \\
\text { Generally, teamwork is being practiced and encourage in a firm. }\end{array}$ & {$[104,108,110]$} \\
\hline $\begin{array}{l}\text { Organizational } \\
\text { Memory }\end{array}$ & $\begin{array}{l}\text { The business organization maintains a comprehensive record of } \\
\text { its employees and experts regarding their field of expertise. } \\
\text { Whenever someone requires such information, it would be } \\
\text { accessible. } \\
\text { A complete customer database was developed and maintained } \\
\text { by the business organization. } \\
\text { The records and databases maintained by the business } \\
\text { organization are always accessible for its employees. } \\
\text { The business organization frequently updates its databases. }\end{array}$ & {$[104,105,108-110]$} \\
\hline
\end{tabular}


Following Wang and Hou (2015), education and age were taken as control variables in this study to examine the probable variations between studied SMEs and their possible effects on Organizational innovation processes.

\section{Results and Discussions}

The study has reviewed the sample response rate, sample characteristics, and summarized the results based on the mean and standard deviation of the sample studied.

\subsection{Descriptive Analysis}

In a sample of 350 firms from Lahore and Gujranwala divisions of Pakistan, the study survey was distributed. As a result of individual efforts made by researchers in the first attempt and follow-ups, 232 responses were attained, and the study rate of response remained $66 \%$. The response rate of $50 \%$ was considered acceptable. A response rate of $60 \%$ was deemed to be good, while the response rate of 70 was supposed to be outstanding for analysis and writing in a research Mugenda and Mugenda [111]. Out of 232 reordered responses, 14 were dropped because of missing responses. The criteria used to remove or discard a questionnaire was $25 \%$ of the total responses. Considering the age of respondents, most of the study participants lie in the last group, i.e., $40.4 \%$, the exact percentage of each group is given in Table 4 . In terms of education, respondents having secondary school certificate (SSC) were $7.8 \%$, higher secondary school certificate (HSSC) $11.1 \%$, Bachelors $31.1 \%$, Masters $47.8 \%$, and above master's $2.2 \%$.

Table 4. Demographic characteristics of the sample.

\begin{tabular}{ccc}
\hline Characteristic & Frequency & Percentage \\
\hline Age & & \\
26-30 year & 16 & 7.4 \\
$31-35$ & 28 & 12.8 \\
$36-40$ & 35 & 16.1 \\
$41-45$ & 51 & 23.3 \\
46 and above & 88 & 40.4 \\
Education & & \\
SSC & 20 & 9.2 \\
HSSC & 29 & 13.3 \\
Graduation & 75 & 34.4 \\
Masters & 86 & 39.4 \\
Above Masters & 08 & 3.7 \\
\hline Total & 218 & 100 \\
\hline
\end{tabular}

\subsection{Measurement Model}

To examine the reliability of all the constructs and items used in the survey, the researchers calculated the Cronbach's alpha values, which were 0.91 to 0.77 . Nunnally and Bernstein (1994) illustrated that Cronbach's alpha value of higher than 0.70 is good and considered as standard for measuring reliability. Therefore, all of Cronbach's alpha values of this study are deemed reliable. The convergent validity and discriminant validity for the used research model was determined through confirmatory factor analysis (CFA). The standard range for factor load values was described as 0.60 at $\mathrm{p}$-value of less than 0.001 , all factor loading values in this study remained above standard range, and the threshold level for the sum of composite reliability (CR) was described as 0.70 , all sum of CR in this study remained well above the standard range. The cut-off point for the sum of average variance extracted (AVE) values was described as 0.50 , all the sum of AVE values for this study remained well above the cut-off point [112]. The mean, standard deviation, items and constructs, factor loadings, $\mathrm{AVE}, \mathrm{CR}$, and $\mathrm{C} \alpha$ for the survey instrument are given in Table 5. 
Table 5. Reliability and validity.

\begin{tabular}{|c|c|c|c|c|c|c|c|}
\hline Construct & Mean & SD & Item & Loading & AVE & CR & $\mathrm{C} \alpha$ \\
\hline \multirow{5}{*}{ KM } & 3.58 & 0.52 & KM1 & $0.88^{* * *}$ & 0.66 & 0.84 & 0.91 \\
\hline & & & KM2 & $0.86^{* * *}$ & & & \\
\hline & & & KM3 & $0.77^{* * *}$ & & & \\
\hline & & & KM4 & $0.68^{* * *}$ & & & \\
\hline & & & KM5 & $0.82 * * *$ & & & \\
\hline \multirow{3}{*}{ OI } & 3.72 & 0.60 & OI1 & $0.90^{* * *}$ & 0.74 & 0.88 & 0.86 \\
\hline & & & OI2 & $0.76^{* * *}$ & & & \\
\hline & & & OI3 & $0.84^{* *}$ & & & \\
\hline \multirow{4}{*}{ OL } & 3.52 & 0.50 & OL1 & $0.92 * * *$ & 0.58 & 0.92 & 0.77 \\
\hline & & & OL2 & $0.84^{* * *}$ & & & \\
\hline & & & OL3 & $0.82 * * *$ & & & \\
\hline & & & OL4 & $0.78^{* * *}$ & & & \\
\hline
\end{tabular}

Fornell and Larcker's (2018) measures were adopted to measure AVE values and to assess discriminant validity. The square root values of the AVE for each construct was calculated and presented in italic in Table 6 . These values demonstrate that a healthy relationship exists between the studied variables and the proposed model as well as these values illustrates that discriminant validity lies in an acceptable range.

Table 6. The average variance extracted (AVE) and correlation.

\begin{tabular}{cccccc}
\hline Construct & KM & OI & OL & RA & RE \\
\hline KM & 0.82 & & & & \\
OI & 0.52 & 0.78 & & & \\
OL & 0.66 & 0.46 & 0.76 & & \\
Age & -0.12 & -0.02 & -0.24 & 1 & \\
Education & 0.12 & 0.14 & 0.19 & 0.01 & 1 \\
\hline
\end{tabular}

The current study used tools like Root-mean-square error of approximation (RMSEA), goodness-of-fit index (GFI), and Chi-square minimum/df (CMIN/df) to measure the fitness of the model. The comparative fit index (CFI), the adjusted goodness of fit index (AGFI), and the normed fit index (NFI) were also employed as appropriate supplementary measures. Additionally, the study used Parsimonious-fit measures like parsimony goodness of fit index (PGFI) and parsimony normed fit index (PNFI). The values given in Table 7 for all the fitness indicators used to measure the reliability and validity of the model used in the current study demonstrates that these values lie in an acceptable range, and the fitness indicators meet the required standards.

Table 7. Fit index of the confirmatory factor analysis (CFA) model.

\begin{tabular}{ccc}
\hline Fit Index & Score & Recommended Threshold Value \\
\hline Absolute fit measures & & \\
CMIN/df & 1.676 & $\leq 2^{\mathrm{a}} ; \leq 5^{\mathrm{b}}$ \\
GFI & 0.842 & $\geq 0.90^{\mathrm{a}} ; \geq 0.80^{\mathrm{b}}$ \\
RMSEA & 0.052 & $\leq 0.80^{\mathrm{a}} ; \leq 0.10^{\mathrm{b}}$ \\
Incremental fit measures & 0.944 & $\geq 0.90^{\mathrm{a}}$ \\
NFI & 0.822 & $\geq 0.90^{\mathrm{a}} ; \geq 0.80^{\mathrm{b}}$ \\
AGFI & 0.926 & $\geq 0.90^{\mathrm{a}}$ \\
CFI & 0.766 & Greater is good \\
Parsimonious fit measures & 0.822 & Greater is good \\
PGFI &
\end{tabular}

a Acceptability: yes, acceptable; ${ }^{b}$ Acceptability: marginal. 


\subsection{Structural Model}

In this phase, we assessed the procedure by determining how to measure the results of an inner structural model. The proposed hypotheses of the current study were tested through SEM technique. The findings of the study were presented in Table 8 and Figure 2.

Table 8. Structural equation modeling (SEM) results.

\begin{tabular}{cccccc}
\hline Hypotheses & Relationship & Anticipated Impact & Estimate & $p$-Value & Result \\
\hline H-1 & KM OI & + & $0.684^{* * *}$ & $<0.001$ & Confirmed \\
H-2 & KM OL & + & $0.593^{* * *}$ & $<0.001$ & Confirmed \\
H-3 & OL OI & + & $0.334^{* * *}$ & $<0.001$ & Confirmed \\
H-4 & KM OL OI & + & $0.174^{* * *}$ & $<0.001$ & Confirmed \\
$(\mathrm{C} / \mathrm{V})$ & Age OI & + & -0.046 & 0.234 & Not-confirmed \\
$(\mathrm{C} / \mathrm{V})$ & Education OI & + & $0.187^{* * *}$ & $<0.001$ & Confirmed \\
\hline
\end{tabular}

Note: $\mathrm{C} / \mathrm{V}=\mathrm{Control}$ variables and ${ }^{* * *} p<0.001$.

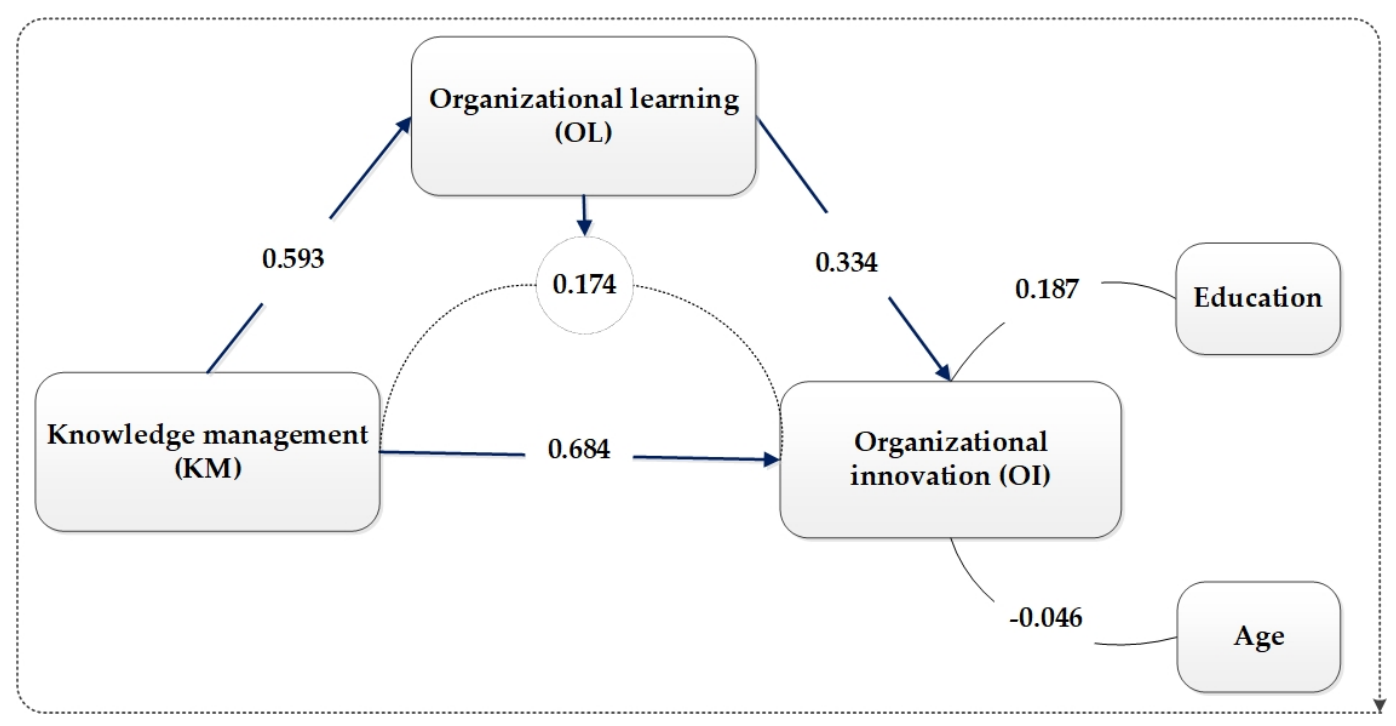

Figure 2. Structural model path coefficients.

\subsubsection{Analysis of Direct Effects}

The direct effects between the dependent variable and the independent variable were described in Figure 2 and Table 8. Hypothesis 1 claimed, "There is a significant positive relationship between KM and OI for the sustainable performance of garments sector SMEs in Lahore and Gujranwala". According to the findings of the study, a statistically significant and positive relationship exists among all the variables studied. Besides, a considerable impact of the proposed hypotheses was also found, and the results of the study supported all proposed hypotheses. Hypothesis 1 demonstrated a positive and significant correlation of knowledge management on organizational innovation, and results $(\mathrm{KM}=0.684, p=0.000)$ confirmed $\mathrm{H} 1$. The study stated, "Knowledge management positively influences organizational learning in the garments sector SMEs of Lahore and Gujranwala Pakistan". Thus, $\mathrm{H} 2$ claimed a positive relationship and impact knowledge management on OL. Findings of Table 8 endorsed $\mathrm{H} 2$ of the study ( $\mathrm{KM}=0.593, p=0.001)$. Then this model prosed, "OL positively influences the organizational innovation in garments sector SMEs of Lahore and Gujranwala Pakistan." The study developed $\mathrm{H} 3$ and claimed that organizational learning and organizational innovation are positively correlated, and organizational learning has a considerable positive impact on OI. The results, as indicated in Table 8, endorsed $\mathrm{H} 3$, and findings have affirmed $(\mathrm{OL}=0.334, p=0.001)$ confirmed H3. This study explained, "Organizational learning mediates the relationship between knowledge 
management and organizational innovation in garments sector SMEs of Lahore and Gujranwala Pakistan." Thus, hypothesis H4 stated, "Organizational learning mediates the relationship between knowledge management and organizational innovation in garments sector SMEs of Lahore and Gujranwala Pakistan." The results of Table 8 endorsed H4 and confirmed the proposed relationships. The results are given in Table 8 also confirm that organizational learning acts as a mediator between knowledge management and organizational innovation $(\mathrm{OL}=0.174, p=0.001)$. The findings of the study also confirm that there is no significant relationship between age and organizational innovation.

\subsubsection{Analyzing Total and Indirect Effect}

This precise study hypothesized the statements and proposed hypotheses for examining the associations between the selected variables of the model. The present research performed a focalized analysis to determine the direct effect of knowledge management on organizational innovation practices. The researchers also investigated the indirect impact of knowledge management on organizational learning.

\section{Conclusions, Findings, and Implications}

\subsection{Findings and Contributions}

Finding the statistical relationship between knowledge management and organizational innovation in garments sector firms of Gujranwala and Lahore was the first objective of the current research study. As indicated in the literature, knowledge management has significant importance for all SMEs as well as for garments sector firms. However, knowledge management has not been given that importance in the garments sector of Pakistan. The researchers, based on the understanding developed through literature, anticipated that a statistical relationship exists between knowledge management and organizational innovation. This proposition was tested and verified through the empirical data and was found significant, as was supported in previous studied [113-115].

Measuring the relationship between knowledge management and organizational learning in the garments sector of Pakistan was the second objective of this study. The practices which play a primary role in sharing and managing knowledge, ideas, and information, as well as sharing of employees' experiences with each other, were the emphasis of this objective. The current research identified that managing and sharing knowledge among employees ultimately supports the industry. The findings of the study establish that a positive and significant relationship exists between knowledge management and organizational learning. This relationship was also reported in previous studies $[18,116,117]$. The next objective of the current research was anticipated for measuring the link among organizational innovation and organizational learning (OI and OL) in garments firms of Gujranwala and Lahore, Pakistan. The findings of the present study reflect that a learning environment has considerable importance for innovation in the garments industry. These findings of a significant and positive impact of organizational learning on organizational innovation are in line with past literature $[44,118,119]$.

The last objective of the present study anticipates measuring the effect of organizational learning as the mediator between the relationship of knowledge management and organizational innovation in garments sector firms of Gujranwala and Lahore, Pakistan. The results indicate that organizational learning completely mediates the relationship between knowledge management and organizational innovation. These findings are in line with the literature $[18,113,119,120]$.

\subsection{Implications and Novelty}

The current study findings can help improve the innovative capability of the garments sector firms of Pakistan if adequately addressed by the policymakers and practitioners. All knowledge management related activities need special attention from managers and practitioners. The knowledge management system adopted by a firm should integrate with its process of innovation. The firms need to enhance their employees' skills and abilities to be able to deal with the available knowledge 
efficiently. The firms also need to increase their spending on strengthening and developing existing knowledge management systems. Organizational learning is considered as an essential factor to fully realize the benefits of knowledge management in terms of innovation.

The value of organizational learning in a firm can be realized through the improvement in abilities, skills, knowledge, and aptitudes of employees while performing different organizational activities and assignments. Therefore, firms in general and garments sector firms expressly are advised to encourage organizational learning activities to improve the effectiveness and efficiency of organizational operations as well as to enhance innovative abilities. The findings of the current study are limited to a specific region as well as a particular sector. Future researchers are advised to focus on other areas and sectors to draw comprehensive solutions [121,122].

The results and findings of the present research have some practical implications for business organizations in general and garments sector firms specifically. The model studied in this research suggests that creation, acquisition, transferring knowledge as well as creating organizational memory for organizational knowledge helps firms in cultivating product, process, and administrative innovation as well as promotes sustainable organizational innovation. Such findings recognize the critical part of knowledge management and organizational learning in starting and managing organizational innovation as well as sustaining it. To promote creation, acquisition, application, and sharing of knowledge for developing competitive advantages, managers can use several learning mechanisms. Moreover, concentrating more on activities related to knowledge management and organizational learning in these firms can devise the root for new, innovative, and creative ideas as well as thoughts, which will ultimately result in better and sustainable organizational innovation. Even further, notably, the study findings recommend the mediating impact of organizational learning. The study suggests that owners and managers in these SMEs are required to dedicate their fullest potential to ensure organizational learning and motivate their employees for learning and improving their abilities and skills for acquiring, generating, applying and sharing experiences and knowledge to enhance the connection between knowledge management and sustainable organizational innovation.

Author Contributions: J.A. and I.H. have completed introduction, literature, methodology, discussion, conclusion, and edited the original manuscript. J.A. and I.H. conceptualized the idea, supervised this project, and designed the method section. M.A.S. contributed to the methodology section, A.A. and S.A. worked on study validation. I.H. and J.A. contributed to writing, review \& editing, the original draft. Q.Z. and J.A. provided resources, funding acquisition, writing, reviewing, and editing the manuscript. All authors have read and agreed to the published version of the manuscript.

Funding: This work is partially supported by the National Natural Science Foundation of China (\# 71572115); Major Program of Social Science Foundation of Guangdong (\# 2016WZDXM005); Natural Science Foundation of SZU (\#836).

Acknowledgments: Special thanks to MDPI professional language editing services to ensure that English grammar is free of mistakes for this manuscript. Ling Jinzhu supervised this project from the School of Media and Communication of Shanghai Jiao Tong University.

Conflicts of Interest: The authors declare no conflict of interest.

\section{References}

1. Tavakoli, I.; Lawton, J. Strategic thinking and knowledge management. Handb. Bus. Strat. 2005, 6, 155-160. [CrossRef]

2. Johannessen, J.-A. Knowledge Management as a Strategic Asset; Emerald Publishing Limited: West Yorkshire, UK, 2018.

3. Mizintseva, M.F.; Gerbina, T.V. Knowledge Management: A Tool for Implementing the Digital Economy. Sci. Tech. Inf. Process. 2018, 45, 40-48. [CrossRef]

4. Ali, H.M.; Ahmad, N.H. Knowledge management in Malaysian bank: A new paradigm. J. Knowl. Manag. Pract. 2006, 7, 1-13.

5. Cegarra-Navarro, J.G.; Jiménez-Jiménez, D.; Fernández-Gil, J.-R. Improving customer capital through relationship memory at a commercial bank in Spain. Knowl. Manag. Res. Pract. 2014, 12, 310-321. [CrossRef] 
6. Barachini, F. Cultural and social issues for knowledge sharing. J. Knowl. Manag. 2009, 13, 98-110. [CrossRef]

7. Adams, G.L.; Lamont, B.T. Knowledge management systems and developing sustainable competitive advantage. J. Knowl. Manag. 2003, 7, 142-154. [CrossRef]

8. Eveleens, C. Innovation management; a literature review of innovation process models and their implications. Science 2010, 800, 900-916.

9. Lin, H.-F. Linking knowledge management orientation to balanced scorecard outcomes. J. Knowl. Manag. 2015, 19, 1224-1249. [CrossRef]

10. Kale, S.; Karaman, A.E. Benchmarking the knowledge management practices of construction firms. J. Civ. Eng. Manag. 2012, 18, 335-344. [CrossRef]

11. Park, H.; Ribière, V.M.; Schulte, W.D. Critical attributes of organizational culture that promote knowledge management technology implementation success. J. Knowl. Manag. 2004, 8, 106-117. [CrossRef]

12. Wiig, K.M. Knowledge Management: An Introduction and Perspective. J. Knowl. Manag. 1997, 1, 6-14. [CrossRef]

13. Wiig, K.M.; De Hoog, R.; Van Der Spek, R. Supporting knowledge management: A selection of methods and techniques. Expert Syst. Appl. 1997, 13, 15-27. [CrossRef]

14. Levinthal, D.; March, J.G. The myopia of learning. Strat. Manag. J. 1993, 14, 95-112. [CrossRef]

15. Huber, G.P. Organizational Learning: The Contributing Processes and the Literatures. Organ. Sci. 1991, 2, 88-115. [CrossRef]

16. Hamid, N.; Nabi, I.; Zafar, R. The Textiles and Garments Sector: Moving Up the Value Chain. Lahore J. Econ. 2014, 19, 283-306. [CrossRef]

17. Fatima, M.; Ahmed, E. Quality Management in Pakistan's Readymade Garments' Industry. Qual. Eng. 2005, 17, 459-465. [CrossRef]

18. Liao, S.-H.; Wu, C.-C. System perspective of knowledge management, organizational learning, and organizational innovation. Expert Syst. Appl. 2010, 37, 1096-1103. [CrossRef]

19. Shujahat, M.; Sousa, M.J.; Hussain, S.; Nawaz, F.; Wang, M.; Umer, M. Translating the impact of knowledge management processes into knowledge-based innovation: The neglected and mediating role of knowledge-worker productivity. J. Bus. Res. 2019, 94, 442-450. [CrossRef]

20. Andreeva, T.; Kianto, A. Knowledge processes, knowledge-intensity and innovation: A moderated mediation analysis. J. Knowl. Manag. 2011, 15, 1016-1034. [CrossRef]

21. Van Aswegen, M.; Retief, F.P. The role of innovation and knowledge networks as a policy mechanism towards more resilient peripheral regions. Land Use Policy 2020, 90, 104259. [CrossRef]

22. Lopez-Nicolas, C.; Meroño-Cerdan, A.L. Strategic knowledge management, innovation and performance. Int. J. Inf. Manag. 2011, 31, 502-509. [CrossRef]

23. Easterby-Smith, M.; Lyles, M. Re-reading Organizational Learning: Selective memory, forgetting, and adaptation. Acad. Manag. Perspect. 2003, 17, 51-55. [CrossRef]

24. Jennex, M.E. What is knowledge management? In Knowledge Management in Modern Organizations; IGI Global: Hershey, PA, USA, 2007; pp. 1-9.

25. Bonfiglio, A.; Camaioni, B.; Coderoni, S.; Esposti, R.; Pagliacci, F.; Sotte, F. Are rural regions prioritizing knowledge transfer and innovation? Evidence from Rural Development Policy expenditure across the EU space. J. Rural Stud. 2017, 53, 78-87. [CrossRef]

26. Senge, P. Sharing Knowledge: You can't own knowledge, so why not share it? Exec. Excell. 1998, 15, 11-12.

27. Baum, J.A.; Ingram, P. Survival-Enhancing Learning in the Manhattan Hotel Industry, 1898-1980. Manag. Sci. 1998, 44, 996-1016. [CrossRef]

28. Sveiby, K.-E. A knowledge-based theory of the firm to guide in strategy formulation. J. Intellect. Cap. 2001, 2, 344-358. [CrossRef]

29. Lant, T.K.; Argote, L. Organizational Learning: Creating, Retaining, and Transferring Knowledge. Adm. Sci. Q. 2000, 45, 622. [CrossRef]

30. Davenport, T.; Prusak, L. Working Knowledge: How Organizations Manage What They Know; Harvard Business School Press: Boston, MA, USA, 1998; Volume 5.

31. Seng, C.V.; Zannes, E.; Pace, R.W. The contributions of knowledge management to workplace learning. J. Work. Learn. 2002, 14, 138-147. [CrossRef]

32. Du Plessis, M. The role of knowledge management in innovation. J. Knowl. Manag. 2007, 11, 20-29. [CrossRef] 
33. Cabeza-Pullés, D.; Fernández-Pérez, V.; Roldán-Bravo, M.I. Internal networking and innovation ambidexterity: The mediating role of knowledge management processes in university research. Eur. Manag. J. 2019. [CrossRef]

34. Argote, L. Organizational Learning: Creating, Retaining and Transferring Knowledge; Springer: New York, NY, USA, 2012.

35. Bahadori, M.; Hamouzadeh, P.; Qodoosinejad, J.; Yousefvand, M. Organizational learning capabilities of nurses in Iran. Glob. Bus. Manag. Res. 2012, 4, 248.

36. Rahimi, M.; Katal, M. Metacognitive strategies awareness and success in learning English as a foreign language: An overview. Procedia Soc. Behav. Sci. 2012, 31, 73-81. [CrossRef]

37. Morales, V.J.G.; Jiménez-Barrionuevo, M.M.; Gutierrez-Gutierrez, L. Transformational leadership influence on organizational performance through organizational learning and innovation. J. Bus. Res. 2012, 65, 1040-1050. [CrossRef]

38. Bao, Y.; Chen, X.; Zhou, K.Z. External learning, market dynamics, and radical innovation: Evidence from China's high-tech firms. J. Bus. Res. 2012, 65, 1226-1233. [CrossRef]

39. Cohen, W.M.; Levinthal, D. Absorptive Capacity: A New Perspective on Learning and Innovation. Adm. Sci. Q. 1990, 35, 128-152. [CrossRef]

40. Liao, S.H.; Chang, W.J.; Hu, D.C.; Yueh, Y.L. Relationships among organizational culture, knowledge acquisition, organizational learning, and organizational innovation in Taiwan's banking and insurance industries. Int. J. Hum. Resour. Manag. 2012, 23, 52-70. [CrossRef]

41. Wignaraja, G. Innovation, learning, and exporting in China: Does R\&D or a technology index matter? J. Asian Econ. 2012, 23, 224-233.

42. Gachanja, I.M.; Nga'nga, S.I.; and Kiganane, L.M. Influence of organization learning on innovation output in manufacturing firms in Kenya. Int. J. Innov. Stud. 2020. [CrossRef]

43. Calantone, R.J.; Cavusgil, S.T.; Zhao, Y. Learning orientation, firm innovation capability, and firm performance. Ind. Mark. Manag. 2002, 31, 515-524. [CrossRef]

44. Sanz-Valle, R.; Naranjo, J.; Jiménez-Jiménez, D.; Perez-Caballero, L. Linking organizational learning with technical innovation and organizational culture. J. Knowl. Manag. 2011, 15, 997-1015. [CrossRef]

45. Weerawardena, J.; O'Cass, A.; Julian, C. Does industry matter? Examining the role of industry structure and organizational learning in innovation and brand performance. J. Bus. Res. 2006, 59, 37-45. [CrossRef]

46. Ar, I.M.; Baki, B. Antecedents and performance impacts of product versus process innovation. Eur. J. Innov. Manag. 2011, 14, 172-206.

47. Choi, B.; Lee, H. Knowledge management strategy and its link to knowledge creation process. Expert Syst. Appl. 2002, 23, 173-187. [CrossRef]

48. Hansen, M.T.; Nohria, N.; Tierney, T. What's your strategy for managing knowledge. Knowl. Manag. Yearb. 1999, 77, 106-116.

49. Zack, M.H. A strategic pretext for knowledge management. In Proceedings of the Third European Conference on Organizational Knowledge, Learning and Capabilities, Athens, Greece, 5-6 April 2002.

50. Wijnhoven, F. Acquiring Organizational Learning Norms. Manag. Learn. 2001, 32, 181-200. [CrossRef]

51. Gnyawali, D.; Stewart, A.C. A Contingency Perspective on Organizational Learning: Integrating Environmental Context, Organizational Learning Processes, and Types of Learning. Manag. Learn. 2003, 34, 63-89. [CrossRef]

52. Brix, J. Exploring knowledge creation processes as a source of organizational learning: A longitudinal case study of a public innovation project. Scand. J. Manag. 2017, 33, 113-127. [CrossRef]

53. Drucker, P. Concept of the Corporation; Routledge: Abingdon, UK, 2017.

54. Agrote, L. Organization learning: A theoretical framework. In Organizational Learning; Springer: Berlin/Heidelberg, Germany, 2013; pp. 31-56.

55. Smith, B.D. Handbook of Organizational Learning and Knowledge Management, 2nd Edition Edited by Mark Easterby-Smith and Majorie A Lyles Wiley, 2011, paperback, 710pp ISBN: 978-0-470-97264-9. J. Med. Mark. 2011, 11, 331-332. [CrossRef]

56. Beugelsdijk, S. Strategic Human Resource Practices and Product Innovation. Organ. Stud. 2008, $29,821-847$. [CrossRef]

57. Damanpour, F. Organizational innovation: A meta-analysis of effects of determinants and moderators. Acad. Manag. J. 1991, 34, 555-590. 
58. Garwin, D. Building a learning organization. Harv. Bus. Rev. 1993, 71, 73-91.

59. Lumpkin, G.; Lichtenstein, B.B. The Role of Organizational Learning in the Opportunity-Recognition Process. Entrep. Theory Pract. 2005, 29, 451-472. [CrossRef]

60. Ganco, M. Cutting the Gordian knot: The effect of knowledge complexity on employee mobility and entrepreneurship. Strat. Manag. J. 2013, 34, 666-686. [CrossRef]

61. Cegarra-Navarro, J.-G.; Jimenez-Jimenez, D.; Garcia-Perez, A. An Integrative View of Knowledge Processes and a Learning Culture for Ambidexterity: Toward Improved Organizational Performance in the Banking Sector. IEEE Trans. Eng. Manag. 2019, 1-10. [CrossRef]

62. Arundel, A.; Casali, L.; Hollanders, H. How European public sector agencies innovate: The use of bottom-up, policy-dependent and knowledge-scanning innovation methods. Res. Policy 2015, 44, 1271-1282. [CrossRef]

63. Pangarso, A.; Astuti, E.S.; Raharjo, K.; Afrianty, T.W. Data of innovation ambidexterity as a mediator in the absorptive capacity effect on sustainable competitive advantage. Data Brief 2020, 29, 105200. [CrossRef]

64. Kuncoro, W.; Suriani, W.O. Achieving sustainable competitive advantage through product innovation and market driving. Asia Pac. Manag. Rev. 2018, 23, 186-192. [CrossRef]

65. Abbas, J.; Hussain, I.; Hussain, S.; Akram, S.; Shaheen, I.; Niu, B. The impact of knowledge sharing and innovation on sustainable performance in islamic banks: A mediation analysis through a SEM approach. Sustainability 2019, 11, 4049. [CrossRef]

66. Abass, F.; Hayat, M.; Shahzad, A.; Riaz, A. Analysis of knowledge management in the public sector of Pakistan. Eur. J. Soc. Sci. 2011, 19, 471-478.

67. Nawaz, M.S.; Shaukat, S. Impact of knowledge management practices on firm performance: Testing the mediation role of innovation in the manufacturing sector of Pakistan. Pak. J. Commer. Soc. Sci. 2014, 8, 99-111.

68. Akhtar, C.S.; Arif, A. Impact of organizational learning on organizational performance: Study. Int. J. Acad. Res. 2011, 3, 327-331.

69. Johnson, G. Research Methods for Public Administrators; Routledge: Abingdon, UK, 2014.

70. McNabb, D.E. Research Methods in Public Administration and Nonprofit Management; Routledge: Abingdon, UK, 2015.

71. Creswell, J.W.; Creswell, J.D. Research Design: Qualitative, Quantitative, and Mixed Methods Approaches; SAGE Publications: Thousand Oaks, CA, USA, 2017.

72. Mertens, F.; Saint-Charles, J.; Mergler, D.; Passos, C.J.S.; Lucotte, M. Network Approach for Analyzing and Promoting Equity in Participatory Ecohealth Research. EcoHealth 2005, 2, 113-126. [CrossRef]

73. Saunders, M.N. Research Methods for Business Students, 5/e; Pearson Education India: Bengaluru, India, 2011.

74. Bell, E.; Bryman, A.; Harley, B. Business Research Methods; Oxford University Press: Oxford, UK, 2018.

75. Groves, R.M.; Couper, M.P. Nonresponse in Household Interview Surveys; John Wiley \& Sons: Hoboken, NJ, USA, 2012.

76. Deluga, R.J. Leader-member exchange quality and effectiveness ratings: The role of subordinate-supervisor conscientiousness similarity. Group Organ. Manag. 1998, 23, 189-216. [CrossRef]

77. Sparrowe, R.T.; Liden, R.C. Process and Structure in Leader-Member Exchange. Acad. Manag. Rev. 1997, 22, 522-552. [CrossRef]

78. Seers, A.; Petty, M.M.; Cashman, J.F. Team-member exchange under team and traditional management. Group Organ. Manag. 2016, 20, 18-38. [CrossRef]

79. Major, D.A.; Kozlowski, S.W.; Chao, G.T.; Gardner, P.D. A longitudinal investigation of newcomer expectations, early socialization outcomes, and the moderating effects of role development factors. J. Appl. Psychol. 1995, 80, 418-431. [CrossRef]

80. Parkhe, A. Strategic alliance structuring: A game theoretic and transaction cost examination of interfirm cooperation. Acad. Manag. J. 1993, 36, 794-829.

81. Ullman, J.B.; Bentler, P.M. Structural equation modeling. Handb. Psychol. 2003, 607-634. [CrossRef]

82. Jauch, L.R. Tailoring Incentives for Researchers. Res. Manag. 1976, 19, 23-27. [CrossRef]

83. Gomez-Mejia, L.R.; Balkin, D.B.; Milkovich, G.T. Rethinking rewards for technical employees. Organ. Dyn. 1990, 18, 62-75. [CrossRef]

84. Koning, J.W. Three other R's: Recognition, reward and resentment. Res. Technol. Manag. 1993, 36, 19-29. [CrossRef] 
85. Malhotra, Y.; Galletta, D.F. Extending the technology acceptance model to account for social influence: Theoretical bases and empirical validation. In Proceedings of the 32nd Annual Hawaii International Conference on Systems Sciences. 1999, HICSS-32. Abstracts and CD-ROM of Full Papers, Maui, HI, USA, 5-8 January 1999.

86. Stajkovic, A.D.; Luthans, F. Social cognitive theory and self-efficacy: Goin beyond traditional motivational and behavioral approaches. Organ. Dyn. 1998, 26, 62-74. [CrossRef]

87. Gardner, D.G.; Pierce, J.L. Self-Esteem and Self-Efficacy within the Organizational Context. Group Organ. Manag. 1998, 23, 48-70. [CrossRef]

88. Schaubroeck, J.; Merritt, D.E. Divergent effects of job control on coping with work stressors: The key role of self-efficacy. Acad. Manag. J. 1997, 40, 738-754.

89. Gecas, V.; Schwalbe, M.L. Parental Behavior and Adolescent Self-Esteem. J. Marriage Fam. 1986, 48, 37-46. [CrossRef]

90. Fishbein, M.; Ajzen, I. On construct validity: A critique of Miniard and Cohen's paper. J. Exp. Soc. Psychol. 1981, 17, 340-350. [CrossRef]

91. Fishbein, M.; Ajzen, I. Belief, attitude, intention, and behavior: An introduction to theory and research. J. Bus. Ventur. 1977, 5, 177-189.

92. Robinson, J.P.; Shaver, P.R. Measures of Social Psychological Attitudes; Survey Research Center, Institute for Social Research: Ann Arbor, MI, USA, 1973.

93. James, L.; Price, C.W.M. Handbook of Organizational Measurement; Pitman: Marshfield, WI, USA, 1986.

94. Fisher, R.J.; Maltz, E.; Jaworski, B.J. Enhancing Communication between Marketing and Engineering: The Moderating Role of Relative Functional Identification. J. Mark. 2018, 61, 54-70. [CrossRef]

95. Darroch, J.; McNaughton, R. Beyond market orientation. Eur. J. Mark. 2003, 37, 572-593. [CrossRef]

96. Manis, J.G.; Meltzer, B.N. A Reader in Social Psychology; Allyn and Bacon: Boston, MA, USA, 1978.

97. Heide, J.B.; Miner, A.S. The shadow of the future: Effects of anticipated interaction and frequency of contact on buyer-seller cooperation. Acad. Manag. J. 1992, 35, 265-291. [CrossRef]

98. Jiménez-Jiménez, D.; Sanz-Valle, R. Innovation, organizational learning, and performance. J. Bus. Res. 2011, 64, 408-417. [CrossRef]

99. Atuahene-Gima, K. Resolving the Capability-Rigidity Paradox in New Product Innovation. J. Mark. 2018, 69, 61-83. [CrossRef]

100. Oldham, G.R.; Cummings, A. Employee creativity: Personal and contextual factors at work. Acad. Manag. J. 1996, 39, 607-634.

101. Woodman, R.W.; Sawyer, J.E.; Griffin, R.W. Toward a theory of organizational creativity. Acad. Manag. Rev. 1993, 18, 293-321. [CrossRef]

102. Manu, F.A. Innovation Orientation, Environment and Performance: A Comparison of U.S. and European Markets. J. Int. Bus. Stud. 1992, 23, 333-359. [CrossRef]

103. Hitt, M.A.; Hoskisson, R.E.; Kim, H. International Diversification: Effects on Innovation and Firm Performance in Product-Diversified Firms. Acad. Manag. J. 1997, 40, 767-798.

104. Lei, D.; Slocum, J.W.; Pitts, R.A. Designing organizations for competitive advantage: The power of unlearning and learning. Organ. Dyn. 1999, 27, 24-38. [CrossRef]

105. Slater, S.F.; Narver, J.C. Product-market Strategy and Performance: An Analysis of the Miles and Snow Strategy Types. Eur. J. Mark. 1993, 27, 33-51. [CrossRef]

106. Baker, W.E.; Sinkula, J.M. The Synergistic Effect of Market Orientation and Learning Orientation on Organizational Performance. J. Acad. Mark. Sci. 1999, 27, 411-427. [CrossRef]

107. Hurley, R.F.; Hult, G.T.M. Innovation, Market Orientation, and Organizational Learning: An Integration and Empirical Examination. J. Mark. 1998, 62, 42-54. [CrossRef]

108. Jerez-Gomez, P.; Cespedes-Lorente, J.; Valle-Cabrera, R. Organizational learning capability: A proposal of measurement. J. Bus. Res. 2005, 58, 715-725. [CrossRef]

109. Tippins, M.J.; Sohi, R.S. IT competency and firm performance: Is organizational learning a missing link? Strateg. Manag. J. 2003, 24, 745-761. [CrossRef]

110. Pérez López, S.; Peón, J.M.M.; Ordás, C.J.V. Managing knowledge: The link between culture and organizational learning. J. Knowl. Manag. 2004, 8, 93-104. [CrossRef]

111. Mugenda, O.M.; Mugenda, A.G. Research Methods: Quantitative Qualitative Approaches; ACTS Press: Anaheim, CA, USA, 2003; pp. 46-48. 
112. Hair, J.F., Jr.; Hult, G.T.; Ringle, C.; Sarstedt, M. A Primer on Partial Least Squares Structural Equation Modeling (PLS-SEM); SAGE Publications: Thousand Oaks, CA, USA, 2016.

113. Chen, C.-J.; Huang, J.-W. Strategic human resource practices and innovation performance-The mediating role of knowledge management capacity. J. Bus. Res. 2009, 62, 104-114. [CrossRef]

114. Darroch, J. Knowledge management, innovation and firm performance. J. Knowl. Manag. 2005, 9, 101-115. [CrossRef]

115. Darroch, J.; McNaughton, R. Examining the link between knowledge management practices and types of innovation. J. Intellect. Cap. 2002, 3, 210-222. [CrossRef]

116. Ho, L.-A. What affects organizational performance? The linking of learning and knowledge management. Ind. Manag. Data Syst. 2008, 108, 1234-1254. [CrossRef]

117. Lin, H.-F.; Lee, G.-G. Impact of organizational learning and knowledge management factors on e-business adoption. Manag. Decis. 2005, 43, 171-188. [CrossRef]

118. Alegre, J.; Chiva, R. Assessing the impact of organizational learning capability on product innovation performance: An empirical test. Technovation 2008, 28, 315-326. [CrossRef]

119. Liao, S.-H.; Fei, W.-C.; Liu, C.-T. Relationships between knowledge inertia, organizational learning and organization innovation. Technovation 2008, 28, 183-195. [CrossRef]

120. Andrews, K.M.; Delahaye, B.L. Influences on knowledge processes in organizational learning: The psychosocial filter. J. Manag. Stud. 2000, 37, 797-810. [CrossRef]

121. Abbas, J.; Raza, S.; Nurunnabi, M.; Minai, M.S.; Bano, S. The Impact of Entrepreneurial Business Networks on Firms' Performance Through a Mediating Role of Dynamic Capabilities. Sustainability 2019, 11, 3006. [CrossRef]

122. Abbas, J.; Aman, J.; Nurunnabi, M.; Bano, S. The Impact of Social Media on Learning Behavior for Sustainable Education: Evidence of Students from Selected Universities in Pakistan. Sustainability 2019, 11, 1683. [CrossRef]

(C) 2020 by the authors. Licensee MDPI, Basel, Switzerland. This article is an open access article distributed under the terms and conditions of the Creative Commons Attribution (CC BY) license (http://creativecommons.org/licenses/by/4.0/). 